\title{
Influence of architectural heritage on the identity and present-day value of American-designed universities' campuses in Asia
}

Yan Hong

\begin{abstract}
In this study, through case studies of campus architectural heritage, the preservation of architectural heritage on campuses is explored. In addition, the effects of architectural heritage preservation on the identity of campuses are investigated, and the corresponding effects on present-day value and spatial experience are analysed. The case studies involve early campuses planned in East Asia by Henry Murphy, and they feature American designs and building styles.

In this study, first, the characteristics of the campuses planned by Henry Murphy are analysed. Next, the characteristics of the preserved architectural heritage at Chosen Christian College are analysed. Finally, with a focus on the preservation of architectural heritage at Shanghai College, the value of architectural heritage and the spatial experience associated with campus development are analysed.

Chosen Christian College focused on maintaining the authenticity of buildings, and Shanghai College attempted to consolidate the identity of the campus through maximizing the spatial experience of the architectural heritage group and preserving architectural heritage. Thus, Shanghai College was more influenced by Henry Murphy's master plan in the development and growth of the campus, and tried to carry on the design concept of the architect and the image of the campus. Conversely, Chosen Christian College was able to retain its original design over nearly a century with the use of all-stone buildings, as Henry Murphy proposed, but no significant trace of the early general plan remains.
\end{abstract}

Keywords: Architectural heritage, Evolution of value, Spatial experience, Henry murphy, Master plan for campuses

\section{Introduction}

\section{Research background}

In the late 19th and early 20th centuries, various European architectural styles were brought to Shanghai, China, by foreign architect firms, such as Whitfield \& Kingsmill (the earliest Western architectural firm, established in 1863), Lester, H. \& Co. (1863), Morrison, G. James (1877), Denham, J.E. \& Co (1893), Atkinson \&

\section{Correspondence: yan7983@hotmail.com}

School of Environment and Architecture, University of Shanghai for Science and Technology, 516 Jungong Rd., Yangpu District, Shanghai 200093, People's Republic of China (c) The Author(s). 2020 Open Access This article is licensed under a Creative Commons Attribution 4.0 International License, which permits use, sharing, adaptation, distribution and reproduction in any medium or format, as long as you give appropriate credit to the original author(s) and the source, provide a link to the Creative Commons licence, and indicate if changes were made. The images or other third party material in this article are included in the article's Creative Commons licence, unless indicated otherwise in a credit line to the material. If material is not included in the article's Creative Commons licence and your intended use is not permitted by statutory regulation or exceeds the permitted use, you will need to obtain permission directly from the copyright holder. To view a copy of this licence, visit http://creativecommons.org/licenses/by/4.0/. 
heritage must be considered with the values that meet present-day needs. For example, architectural heritage sites such as the Acropolis and Forbidden City are required to retain commemorative value, whereas modern architectural heritage requires a building to have both use value and art value to reflect present-day values.

Therefore, in this study, through case studies of campus architectural heritage, the preservation of architectural heritage on campuses is investigated. In addition, the influence of architectural heritage preservation on establishing the identity of campuses is explored, and the corresponding effects on present-day value and spatial experience are analysed (Fig. 1).

Architectural heritage is a material property inherited from historical and cultural resources and is often considered in future development. In his work 'The Seven Lamps of Architecture', John Ruskin claimed that: 'The Lamp of Memory: Buildings should respect the culture from which they have developed' (Ruskin 1849, 162182).

Since architecture exists in both space and time, present-day demands should be considered in the context of history. The existing uses and facades should be changed so that the buildings are suited for the current time. Therefore, this study is meaningful in reviewing architectural visions that respect the value of architectural heritage while satisfying the current campus needs.

\section{Research objectives and method}

In this study, the 'coexistence' of present-age architecture and architectural heritage on two campuses is analysed. The campuses are Chosen Christian College in Korea and Shanghai College in China. Henry Murphy developed the master plans for and designed the buildings on both campuses.
Both case studies involve early campus planning completed in East Asia by Henry Murphy, and the campuses feature American campus planning and building styles. Furthermore, both universities have preserved the buildings designed by him. Thus, these universities developed by missionaries in the early twentieth century have important research value.

In this study, first, the characteristics of the campuses planned by Henry Murphy are analysed. Next, the characteristics of the preserved architectural heritage at Chosen Christian College are analysed. Finally, with a focus on the preservation of architectural heritage at Shanghai College, the value of architectural heritage and spatial experience is assessed.

Alois Riegl (1858-1905) divided the values of architectural heritage into commemorative values and presentday values. The commemorative values include the age value, historical value and intentional memorial value, and the present-day values include the use value and art value (Chang 2014, 13-14) (Fig. 2). Therefore, the case studies considered are present-day value studies of architectural heritage that focus on the use status of buildings and changes in the facade components.

The spatial experience of architectural heritage has several characteristics. First, architectural heritage has a specific route centred around space. Second, an architectural heritage space has an identity as a place. As such, an architectural heritage space can serve as a medium of experience; so the user experience should be planned considering the spatial characteristics of the architectural heritage site (Jang et al. 2019, 16).

Since spatial experience involves a series of experience sequences, these experiences are implemented in a path plan for a particular space. In this study, based on the five key physical elements of a city proposed by Kevin Lynch, the spatial experience is analysed. The research

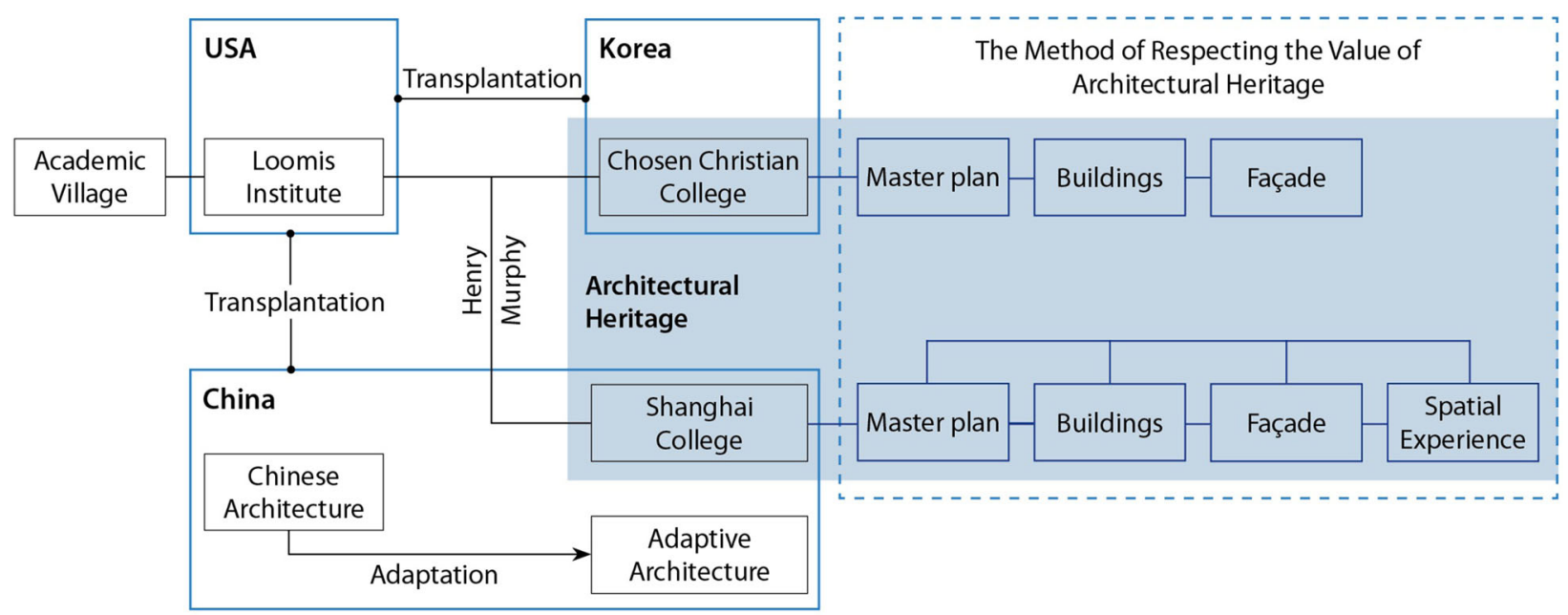

Fig. 1 The research flow chart (Source: the author) 


\section{Evolution of Value According to Riegl}

The definition of the monument expands in the modern era with each stage encompassing the former.

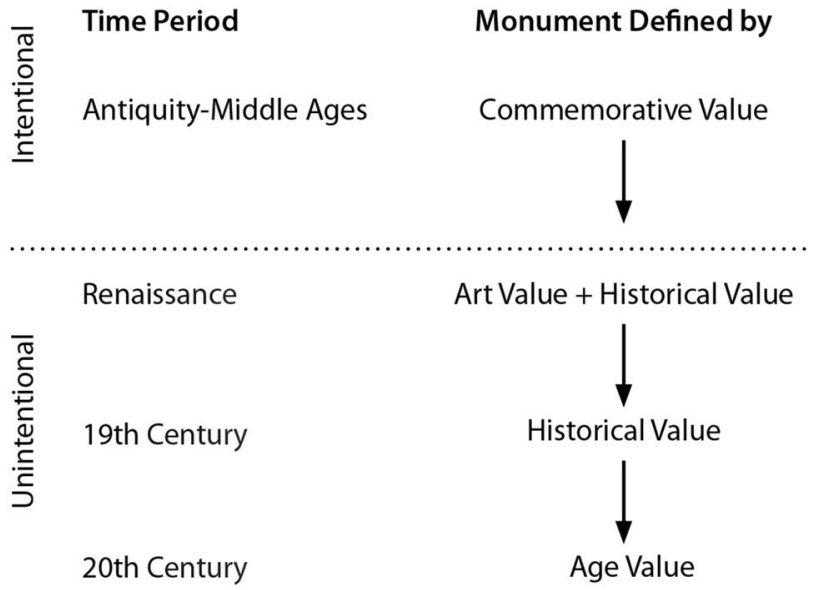

Location of Meaning
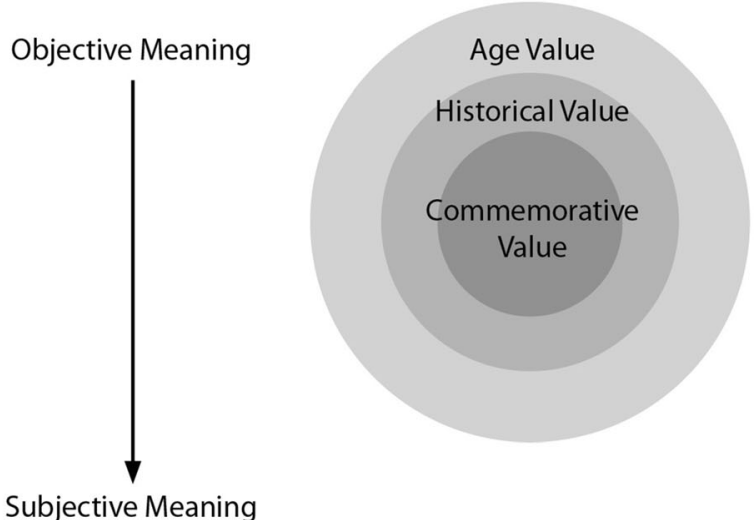

Fig. 2 An interpretation of Riegl's evolutionary scheme of values (Source: Lamprakos 2014, 421)

process was implemented through cross-checking with literature reviews and field surveys.

\section{Campus planning in East Asia \\ Overview}

As early as 1904, Yale-in-China administrators had approached two other Yale graduates to advise them on architectural issues, i.e., Phelps of class 1890, and Atterbury of class 1891, both of New York, USA. The committee then turned to Murphy and Dana, whose reputation for sensitive campus designs for educational clients in Connecticut, USA, was growing by 1913. Further inducing Murphy \& Dana to venture so far was the prospect of designing two other campuses in Asia, both for the American Episcopal Foreign Mission, i.e., St. Paul's College near Tokyo, Japan, and Chosen Christian College in Seoul, Korea (Cody 2001, 21).

In 1906, Murphy opened his own firm with Yale University instructor, Richard Henry Dana Jr., a business partnership that lasted until 1921. Together, they took on work such as designing the early Loomis Institute in 1912, and they successfully earned commissions to design numerous academic college buildings in the northeastern United States and East Asia. According to the Yale University Library Archive, Henry Murphy performed architectural design and campus planning in various Asian countries, including 23 projects in China, two projects in Japan (one of them was St. Paul's College), one project in South Korea (Chosen Christian College), four projects in the Philippines, and one project in Indonesia (Yale University Library 2015).

The work of Henry Murphy can be divided into four series. The first series included more than 100 colonial-style houses built in the U.S. in the first decade of his career; the second included the 'adaptive Chinese Renaissance'; the third series included the design of educational facilities in the U.S.; and the fourth series was the 'foreign style' series established in China (Dho 2002, 71).

Yale-in-China and Shanghai College in China, St. Paul's College in Japan and Chosen Christian College in South Korea all have foreign-style architecture. In East Asia, this style was not only the result of Murphy's design concept, but also a result of the social environment and the clients' wishes. For example, the administrators at St. Paul rejected the use of traditional wooden architecture because the Episcopal Board wanted a more 'permanent' kind of architecture, which to most meant either brick or concrete buildings. This choice of building material; helped to dictate the architectural style, which Murphy referred to as 'modified Gothic,' in partial imitation of Oxford, Cambridge, Princeton and Yale Universities. Murphy and Dana also drew upon what they had designed for the Loomis Institute and the College of New Rochelle (Cody 2001, 30). Furthermore, since Shanghai and the surrounding area have been more tolerant to foreign cultures than have other areas, missionary colleges have been unreservedly accepted by locals with support and assistance. As a result, Soo Chow College, Hangchow University and Shanghai College were all planned with foreign-style architecture (Dong 2010, 27).

Prior to the design of the educational facilities in East Asia, Murphy had already implemented relevant designs in the United States. Murphy \& Dana entered a competition to establish the master plan of the Loomis Institute in Windsor, Connecticut, USA. Murphy \& Dana's design was clearly influenced by Thomas Jefferson's plan for the 
University of Virginia. Loomis also displayed a modified 'Colonial' style (Cody 2001). University campus buildings are rarely designated as architectural and cultural heritage sites by UNESCO. The University of Virginia was the only one in the United States to be listed as a UNESCO heritage site based on the Academic Village designed by Thomas Jefferson.

The Academic Village still forms the heart of the University of Virginia and has a unique U-shaped plan dominated by a rotunda with pavilions, hotels, student rooms, and gardens, which are arranged in rows to the south (UNESCO 2015). The Academic Village concept was referenced in Murphy's layout for the Loomis Institute. The buildings at the campus were also placed in a $\mathrm{U}$-shaped arrangement, resulting in the main axis being highlighted (Fig. 3). Furthermore, the auditorium design for Tsinghua University in Beijing, designed by Henry Murphy in 1917, has the same form as the rotunda in the Academic Village.

\section{Campus planning in China}

While working in Shanghai for nearly two decades, Henry Murphy was part of the Adaptive Chinese Renaissance and influenced China's young architects, such as Yanzhi Lyu and Jun Zhuang (Wu 2001, 13). Yanzhi Lyu and Jun Zhuang were two of the first Chinese architectural students to study in U. S. architectural programs. Henry Murphy's office was one of the first American firms to hire Chinese graduates from American architectural programs. Yanzhi Lyu (1894-1929) achieved fame in the mid-1920s for winning the competition to design the Sun Yat-Sen Memorial Cemetery in Nanjing, China.

Murphy believed that most Chinese builders were unaware of how remarkable Chinese architecture was. $\mathrm{He}$ thought that most foreign architects treated Chinese architecture either as an archeological artifact or a source of ornament to be applied to a foreign plan or facade. In contrast, Murphy professed seeing the architecture of China as a "living organism." He attempted to resuscitate discrete forms of Chinese architecture by invoking them to solve new practical problems. For example, how to plan missionary colleges, with building materials or techniques, such as steel beams and reinforced concrete, which were becoming prevalent in North American architectural practices by the 1910s but was relatively new in China (Jeffrey W. Cody 2001, 5). Henry Murphy developed campus master plans and architectural designs for eight universities in China, including the College of Yale-in-China, Fudan Private University, a group of school buildings for St. Mary's Hall,

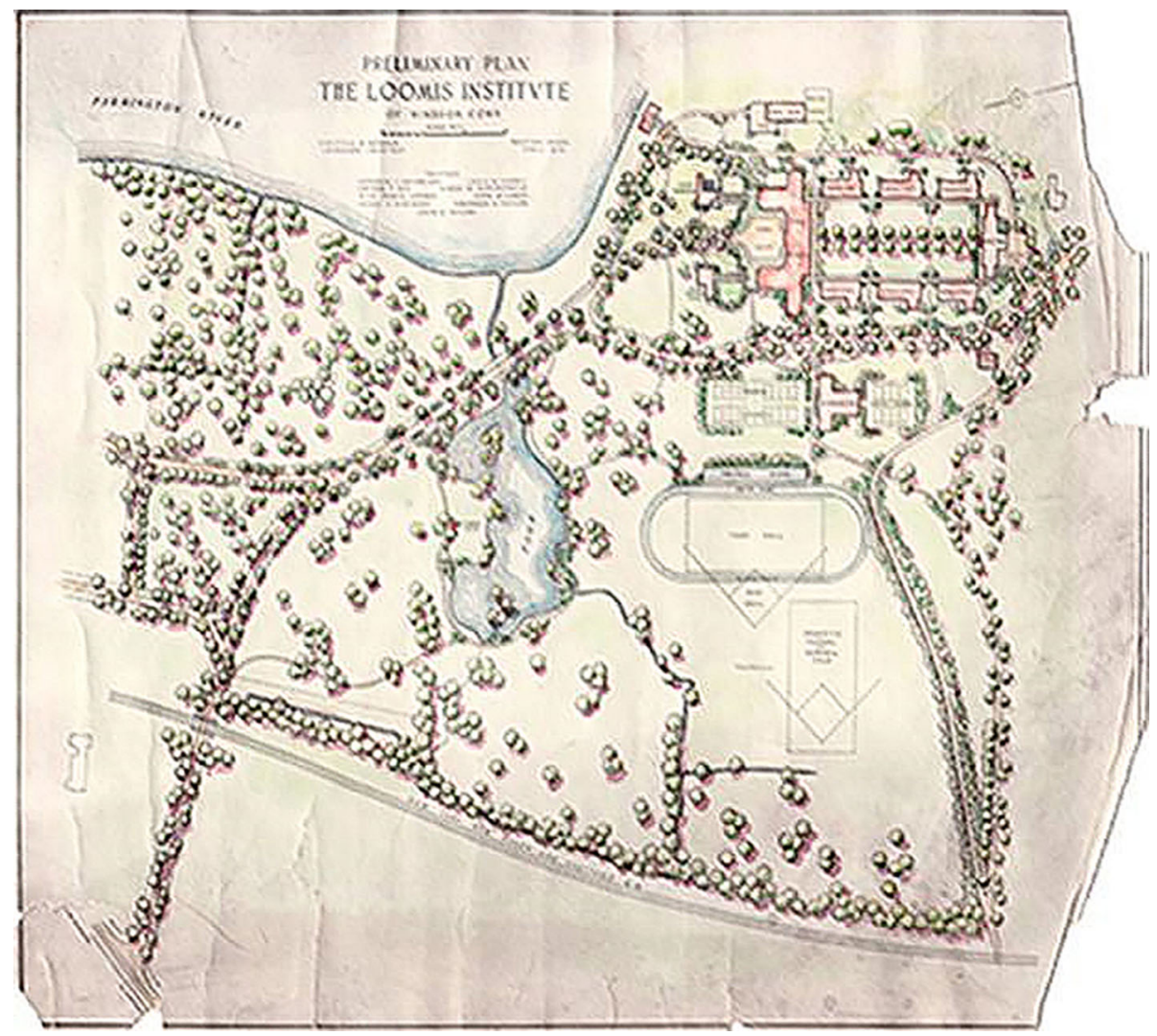

Fig. 3 Master plan for the Loomis Institute (Source: the Loomis Chaffee School Archives) 
Table 1 Rating system of roofs in Chinese feudal society (Image source: Liang 1991, 11)

\begin{tabular}{|c|c|c|c|c|c|}
\hline Hip roof & Gable-and-hip roof & $\begin{array}{c}\text { Overhanging } \\
\text { gable roof }\end{array}$ & Flush gable roof & Pyramidal roof \\
\hline & &
\end{tabular}

the Tsinghua University extension, Fukien Christian University, Ginling College, Yenching University, and Shanghai College.

The roof is the highest realm of Chinese architectural art, and an elegant curved roof is similar to a delicately woven giant aureole (Gresnigt Dom Adelbert 1928, recited from Li Dong 2010, 35-36). As roofs are the most important component of Chinese architecture, Chinese people are very concerned with the way roofs are treated, and many decorations are added so that largescale roofs do not look monotonous (Ito 1984, 50-51) (Table 1). Henry Murphy's adaptive architecture also focused on the Chinese roof.

For example, Chit Sang Hall, Luk Yau Hall, and Xing Pavilion at Canton Christian College (the predecessor of Sun Yat-Sen University) adopted hip roofs and gable-andhip roofs, which are roof types that were only used in palace architecture under the feudal status system (Fig. 4).

Western and Chinese roof constructions, as well as timber arches, can be compared. The West developed the triangulated truss, a rigid construction which inhibits expansion, whereas the beam frame system of China, not based on the triangle above column level, is capable of considerable expansion in all directions (Hitchcock 1963, 83) (Fig. 5). However, Henry Murphy's Chinese-style roof did not start with an understanding of wooden architecture; instead, a method that can be implemented with Western techniques and materials was used. Some signs of this practice can be found in the Western-style roof structure at Ginling College; this design is suitable for building materials such as concrete and brick (Fig. 6).
Henry Murphy's work in China combines Western technologies and Chinese stylistic features under his adaptive architectural approach. However, the introduction of American-style campus planning and the corresponding influence on the development of Chinese campuses are poorly understood.

\section{Foreign-style campus planning in South Korea General plan for chosen Christian College}

The site for the Chosen Christian College campus, was purchased in 1917 with a generous donation from Mr. John T. Underwood, who was the elder brother of college founder Horace Grant Underwood. The college's master plan was drawn up by Murphy \& Dana Architects at its New York headquarters in 1917, and the plan was submitted almost simultaneously with the completion of the site entry (Cultural Heritage Administration of the Republic of Korea 2013c, 63) (Fig. 7).

The problem Murphy faced at the campus site was the selection of the building material for the college's masonry structures. Initially, local bricks seemed the cheapest and best choice. However, due to the bricks' poor weathering qualities and their tendency to disintegrate, it became "a source of considerable anxiety". As Murphy pondered the problem at the site, he was overjoyed to find a building stone that was 'cropping right on the site of the buildings; it is of a beautiful colour and texture, and splendid weathering qualities.' He exclaimed that 'with a sturdy slate roof, we can get all-stone buildings of great effectiveness. Everyone here is delighted at this prospect' (Cody 2001, 67).
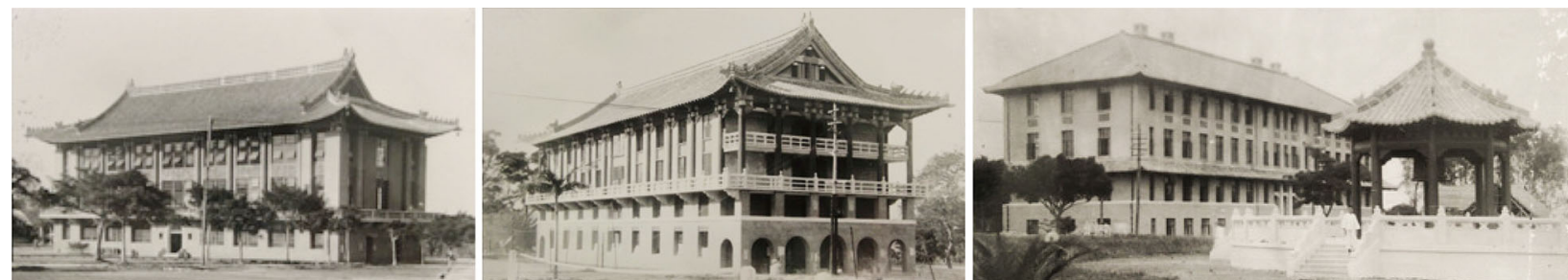

Fig. 4 Chit Sang Hall, Luk Yau Hall, and Xing Pavilion at Canton Christian College (Source: http://www.sysu.edu.cn/cn/zdgk/zdgk08/tuzwq/tuzwq2014/tu201401) 

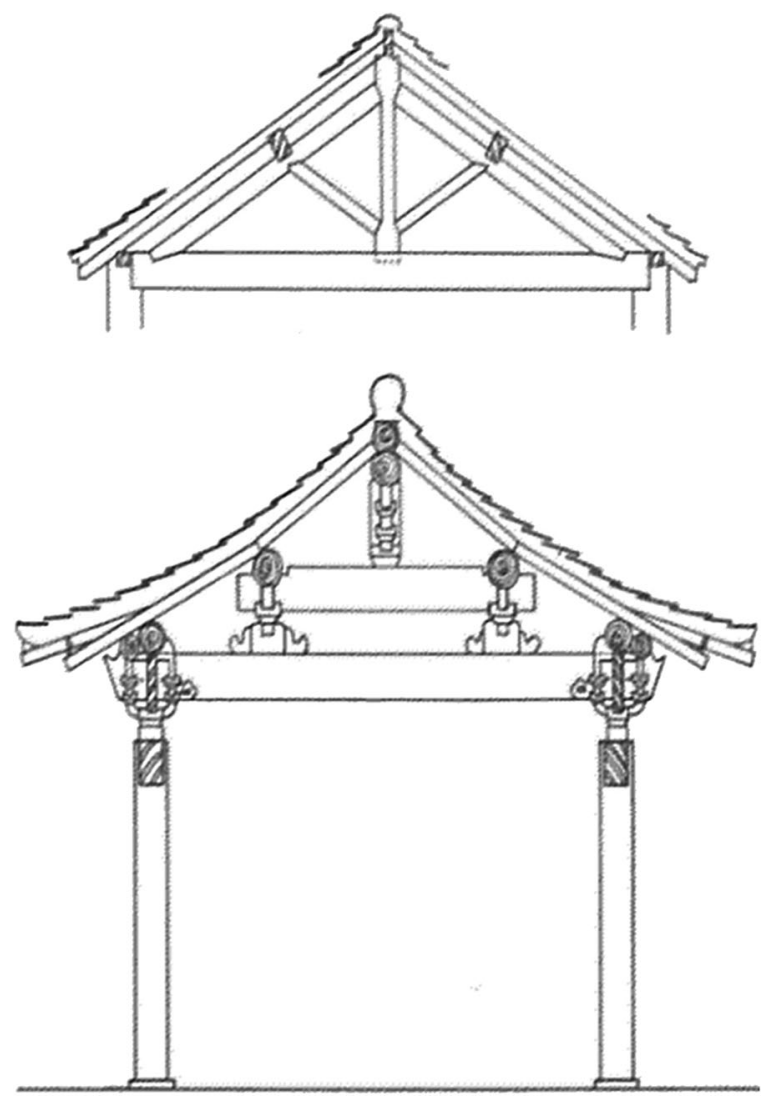

Fig. 5 Comparison of Western and Chinese roof constructions (Source: Hitchcock 1963)
Stimson Hall, Underwood Hall, and Appenzeller Hall, designed by Murphy, were designated as Historic Site by the Korean Cultural Heritage Administration in 1981 (Table 2).

\section{The building layout}

Chosen Christian College was renamed Yonhi College in March 1923, and Yonhi College and Severance Medical College merged into Yonsei University in January 1957.

Yonsei University has only preserved three buildings and the axis of Baekyang Road from Murphy's plan. Stimson Hall was constructed in March 1920, and Underwood Hall and Appenzeller Hall were constructed in April 1924. Although these buildings were preserved as architectural heritage buildings, Henry Murphy's plan has not significantly affected the university's overall growth and evolution. Notably, the Baekyang Road Recreation Project, which was completed in 2015, preserved the axis of Baekyang Road (Table 3).

Stimson Hall, Underwood Hall, and Appenzeller Hall were designed with a symmetrical arrangement based on a U-shaped plan that emphasized the central axis, which is typical of U.S. campuses. Additionally, various facade components were used for each building to maintain diversity among buildings (Lee 2012, 27). These buildings' layout features were the same as those in Murphy's earlier campus plans, such as those for Yale-in-China (1913) and St. Paul's College (1914) (Table 4).

\section{The building design}

The architectural style that Henry Murphy adopted for the buildings has been defined in the literature as 'Collegiate Gothic' (Shin 2006, 14). The adoption of Tudor Gothic architecture for academic structures in the United States provided an important aesthetic

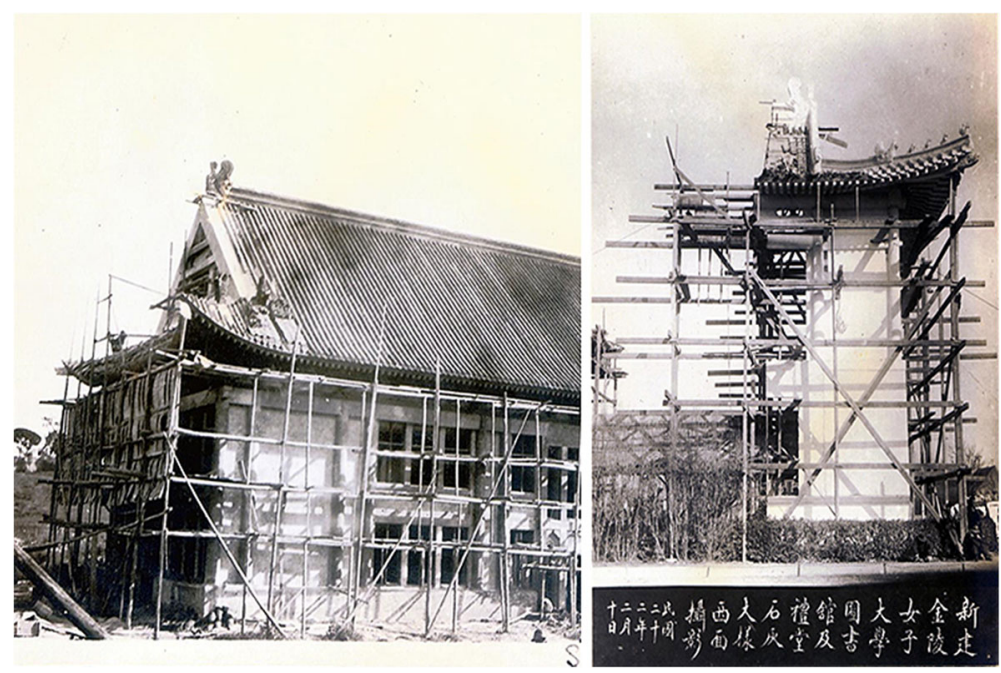

Fig. 6 Construction of campus. Left: ca.1922. Right: ca.1933 (Source: Yale University Library Digital Collections) 


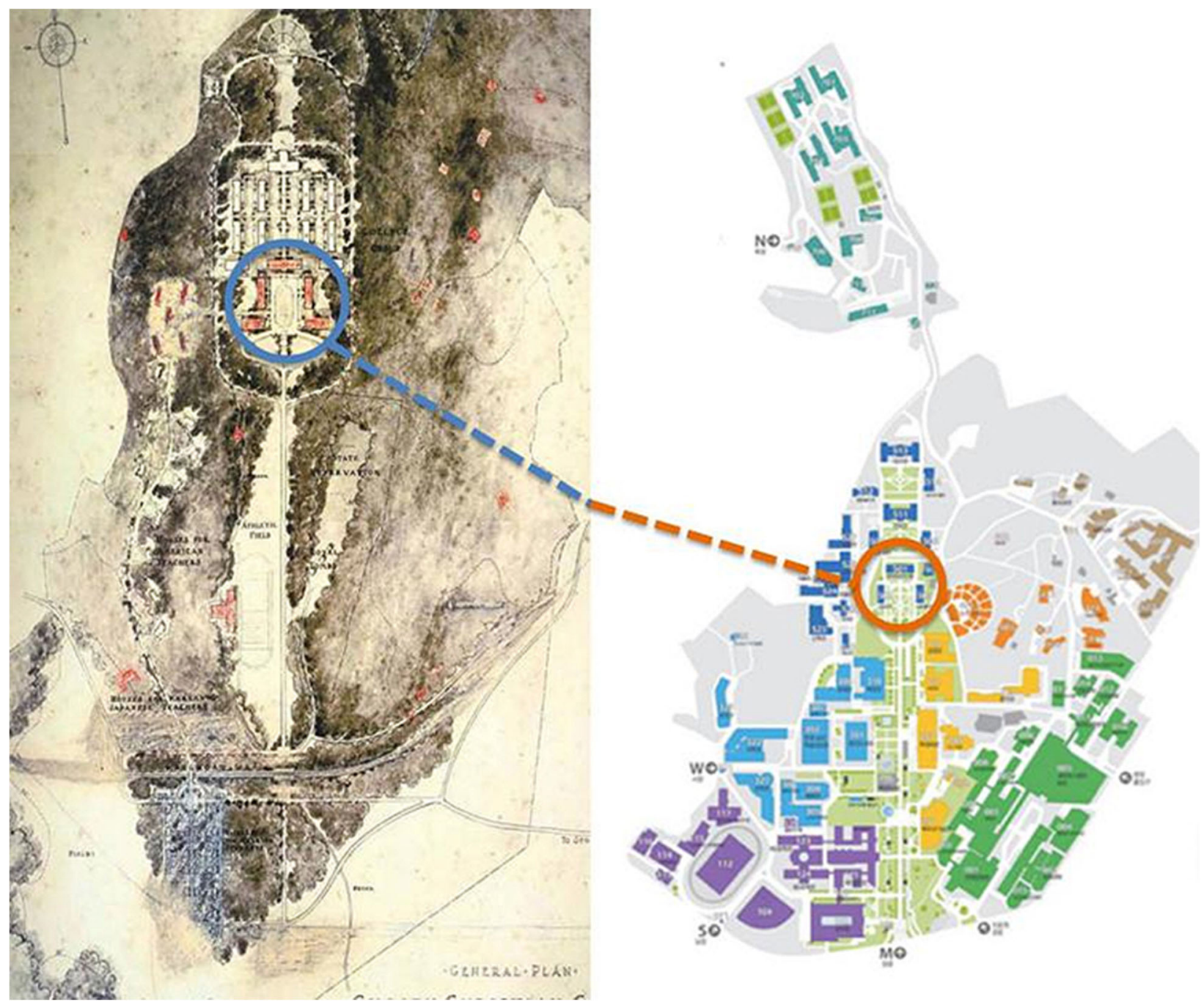

Fig. 7 Left: master plan for Chosen Christian College (Source: Cultural Heritage Administration of the Republic of Korea 2013c, 64). Right: the current campus of Chosen Christian College (Source: Yonsei University Website)

and intellectual bridge between European and American cultures. This architectural style has been called various interchangeable names at different times, including Tudor Gothic, secular Gothic, late Gothic, or Collegiate Gothic style (Goodchild 2000,
274). The Collegiate Gothic style was again exported to Asian campuses through a missionary college led by American missionaries. Among the elements of the Tudor Gothic form, the facade components used in these buildings include oriel windows, window

Table 2 Designated historic site overview at Yonsei University

\begin{tabular}{llll}
\hline Act & Cultural Heritage Protection Act & & \\
\hline Designated organization & Korean Cultural Heritage Administration & & Appenzeller Hall \\
Name of Cultural Heritage & Stimson Hall & Underwood Hall & Historic Site 277 \\
Classification & Historic Site 275 & Historic Site 276 & \\
Age & Japanese Imperialism Period & & 1924 \\
& 1922 & 7924 & $506 \mathrm{~m}^{2}$ \\
Area & $484 \mathrm{~m}^{2}$ & & \\
Designated Date & 1981.09 .25 & & \\
Manager & Yonsei University & & \\
\hline
\end{tabular}


Table 3 The landscape of the architectural heritage at Chosen Christian College (Image source: http://html.dsso.kr)

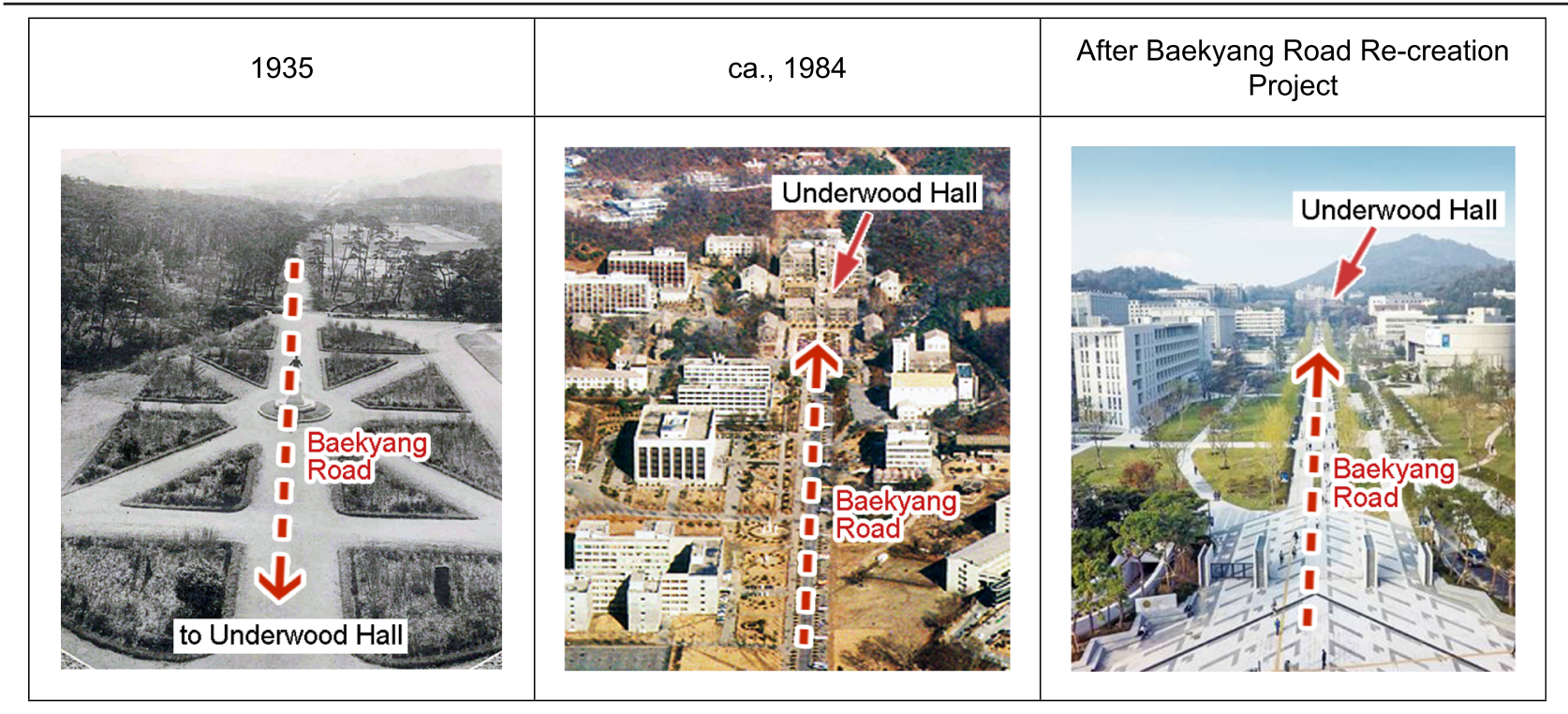

bays, arches, and chimneys. These elements were applied in different ways and in different areas of the three buildings to preserve the characteristics of each building (An 2014, 126) (Fig. 8).

Yonsei University has preserved three buildings designed by Henry Murphy as architectural heritage structures, and their current appearance is similar the original design, thanks in part to the use of stones and plain concretes as the main building materials (Table 5). Furthermore, the axis of Baekyang Road that emerged from Henry Murphy's general plan has been emphasized as the identity of the campus. Overall, the university has focused on the value of each architectural heritage structure, but the campus vision has not been greatly influenced by Henry Murphy.

Robert A. Young divided the criteria for 'historical preservation' into four stages, namely, 'preservation', 'rehabilitation', 'restoration', and 'reconstruction', based on the characteristics and background of the historical architecture (Young 2008). According to the current condition of buildings, Stimson Hall, Underwood Hall, and Appenzeller Hall are in the 'preservation' stage. This stage includes maintaining the current building form, building completeness, and material defects by taking necessary measures.

\section{Summary}

The campus layout plans by Henry Murphy generally surrounded the central exterior space with three or more buildings, and axes with symmetrical layouts of buildings were designed and emphasized. The buildings placed on the main axis play a spatial role, such as forming a rotunda, in Thomas Jefferson's Academic Village concept (Table 6).

The campus planning in Henry Murphy's early works largely continued the American campus style and reflected of the client's direct wishes. Each building facade style adhered to the Collegiate Gothic style from the United States.

\section{Shanghai college as a foreign-style architectural heritage site \\ Overview}

'To the visitor to China in the year 1926, one of the most interesting and thought-provoking features of the landscape was the physical evidence of the activities of Christian missionaries. If the traveler entered the country by Shanghai, on the outskirts of the city, his steamer passed the substantial buildings of an institution which he was informed was Shanghai College, maintained by American Baptists' (Latourette 1929, 1). Henry Murphy completed the general plan for Shanghai College in 1919. The university (now known as the University of Shanghai for Science and Technology) placed a statue of Henry Murphy among the campus's architectural heritage due to the high regard for his influence on campus development (Fig. 9).

Because this campus had to include primary school, middle school, and college educational facilities, both the distinctions among the educational facilities and the independent securing of exterior space became important planning factors. Therefore, the master plan emphasized the zoning classification of the three education spaces. These three educational campuses were penetrated by a single main road, and the road served as an axis that tied each space together. For the layout of the 
Table 4 Henry Murphy's early campus layout plans
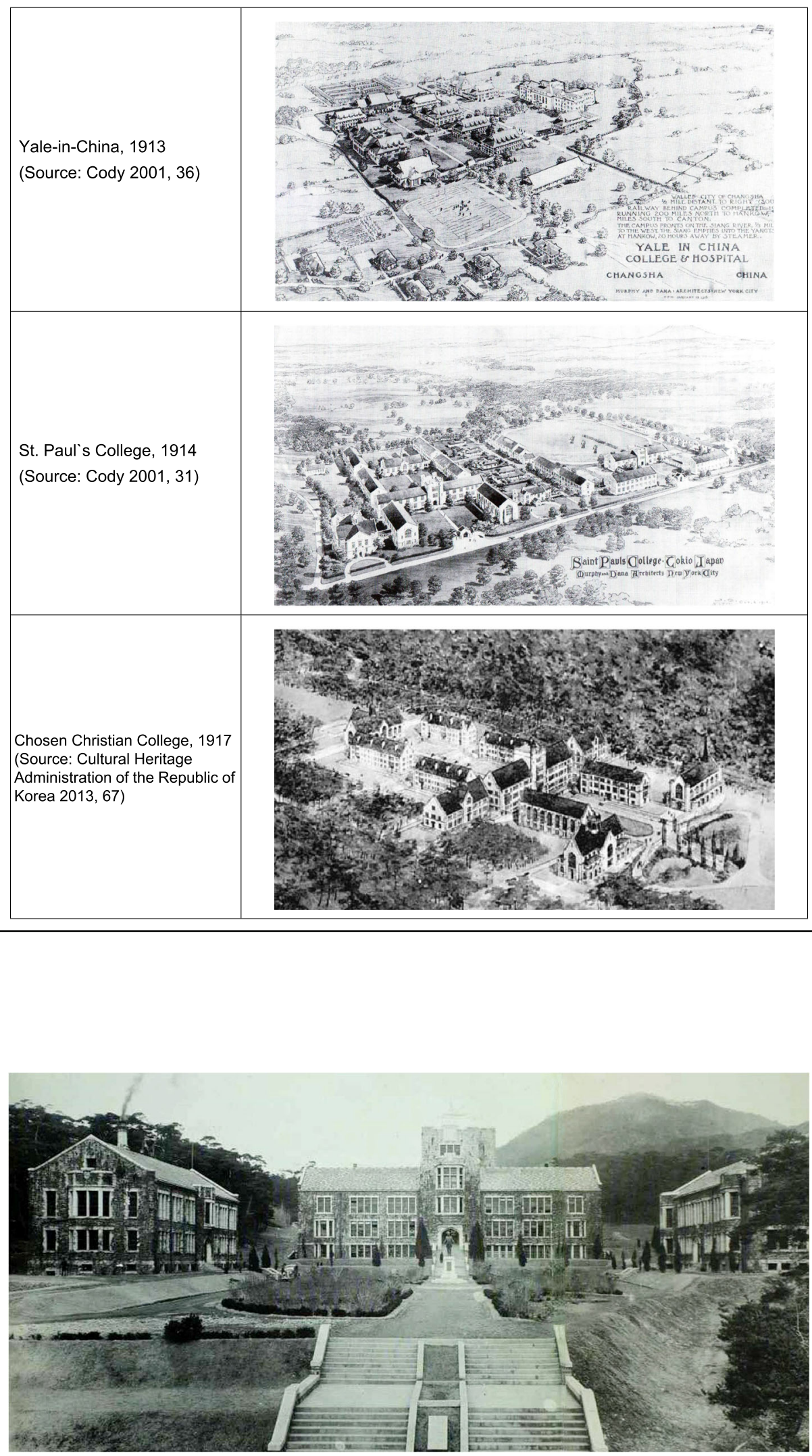

Fig. 8 A panorama of the three buildings, 1928 (Source: Cultural Heritage Administration of the Republic of Korea 2013c, 76) 
Table 5 Architectural heritage design and present situation at Chosen Christian College (Cultural Heritage Administration of the Republic of Korea 2013a, 2013b, 2013c)

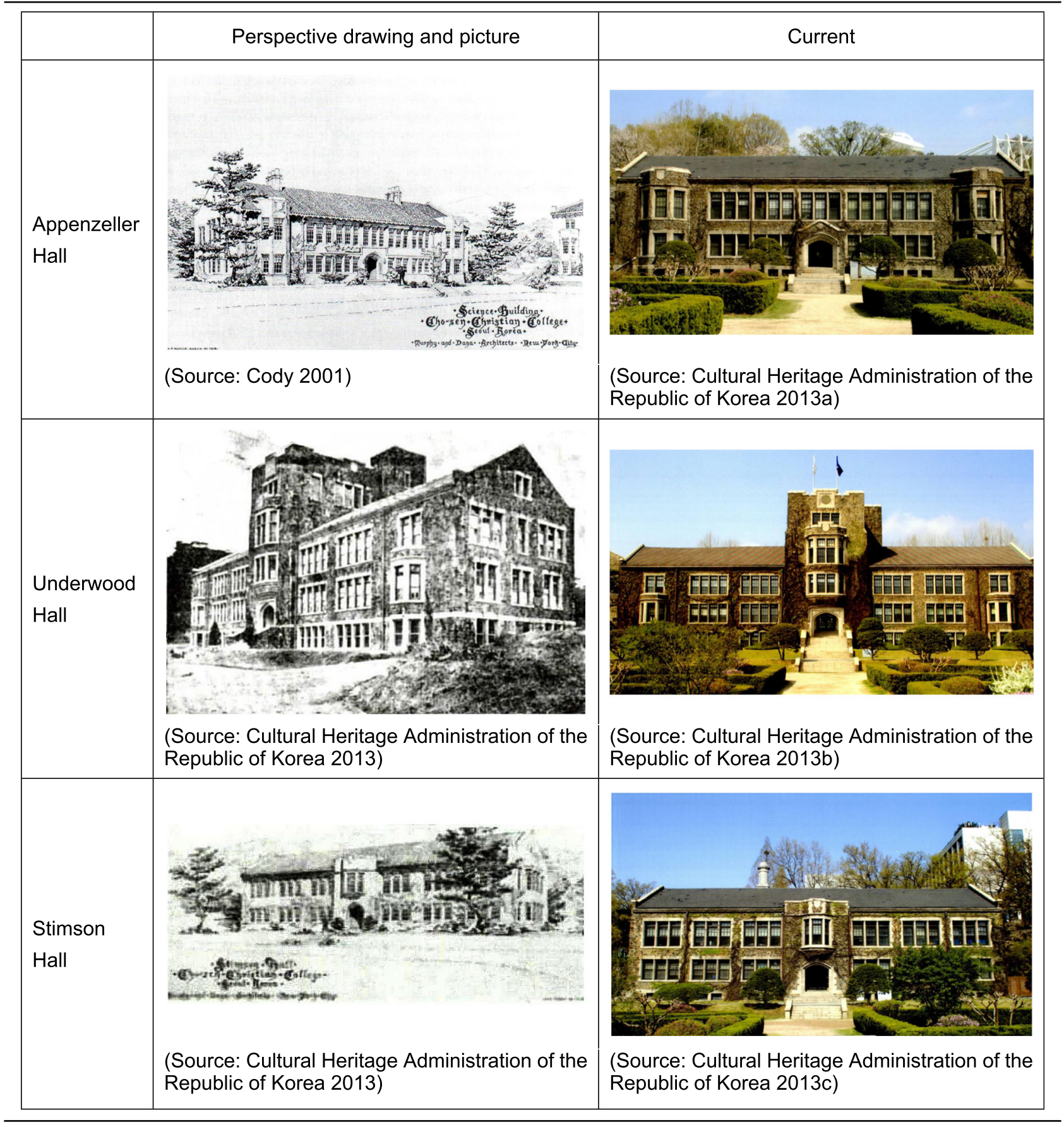

buildings, the relationships among the buildings that had appeared in the work of Murphy have weakened, thereby weakening the characteristics of the exterior space and the axis formed around the buildings.

On the campus of Shanghai College, Murphy maintained an American campus design style. His plans exhibited various features that integrated Western and Chinese architectures. This design has a distinct historical value in
Chinese architecture. For instance, the Shanghai municipal government designated the campus a "heritage architecture" site on February 15, 1994, and October 31, 2005 (Table 7). Murphy adopted the Western campus building style when designing Shanghai College. The campus is similar to the old campus buildings in the U.S., including those at Murphy's alma mater, Yale University (Hong 2016, 470-473) (Fig. 10). 
Table 6 Henry Murphy's college building layout plans

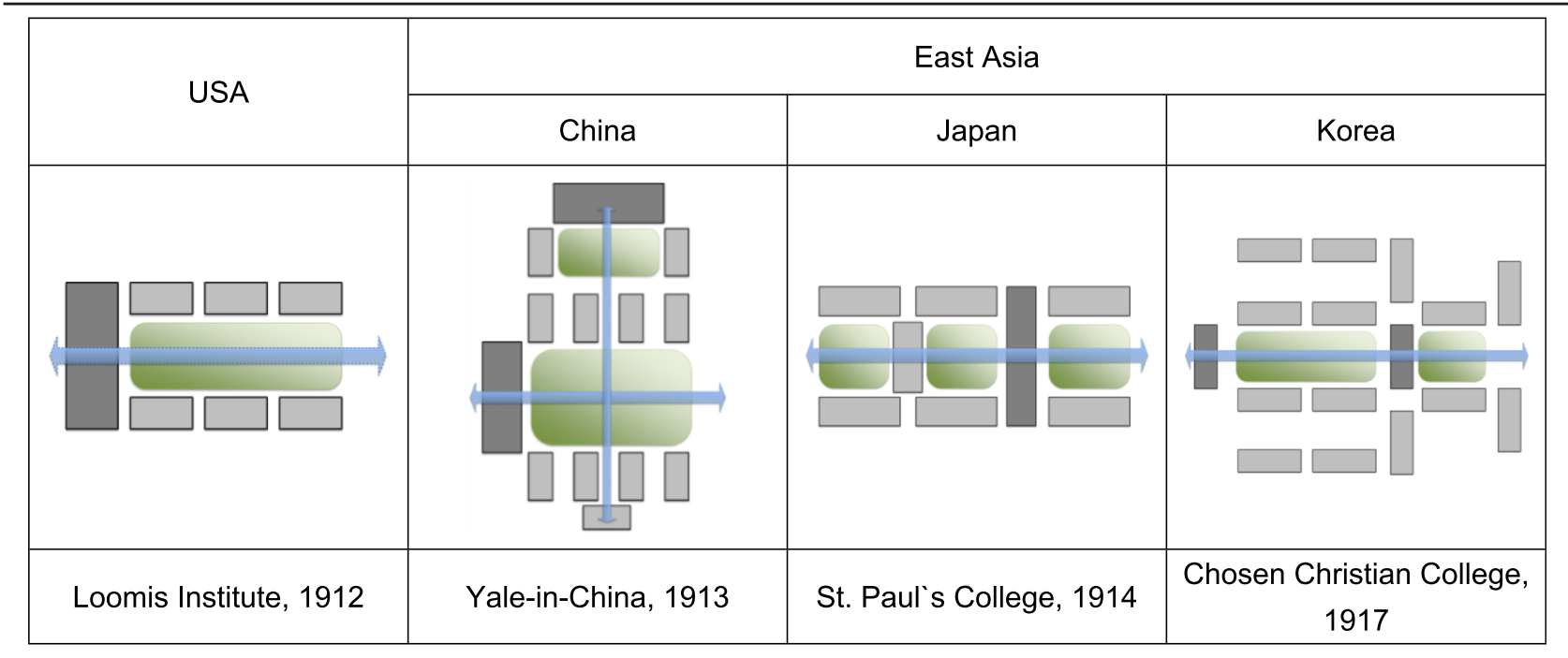

\section{The architectural heritage structures on the current campuses}

Based on the building design in the general plan established by Henry Murphy, the preservation of the buildings designated as heritage architecture in Shanghai was investigated. Yates Hall, the gymnasium, Breaker Hall, Evanston Hall, faculty residences (7 houses, now known as the International Cultural Park-USST), the dining hall (East Hall), Mcleish infirmary, the music hall, Melrose Hall, Richmond Hall, Treat Hall, the auditorium and White Chapel in Henry Murphy's plan have been preserved and designated as heritage architecture structures. (Figs. 11 and 12).

There are some other building types that are different from the existing architectural design style. For example, the Administration building of the College Group was originally planned to be rectangular, but it is now in the form of a L. However, based on the bird's-eye view
(Fig. 13) at the time of construction, the original building had a similar architectural form as the present structure. Therefore, the design had already been revised prior to construction, although this study cannot confirm whether Murphy was the architect who made the modifications. Furthermore the Middle School Group's Recreation Building was actually constructed as Melrose Hall and Richmond Hall. The general plan by Henry Murphy had no Chinese elements in it. Therefore, elements of the Chinese traditional architecture style were not considered, and these elements are still not present on campus.

In Kwan-Seok Lee's study, the coexistence of architectural heritage and contemporary architecture was divided into modesty (placing the building underground or semi-underground), sympathy (considering architectural heritage based on similarity), and contrast and communication (not preserving architectural heritage)
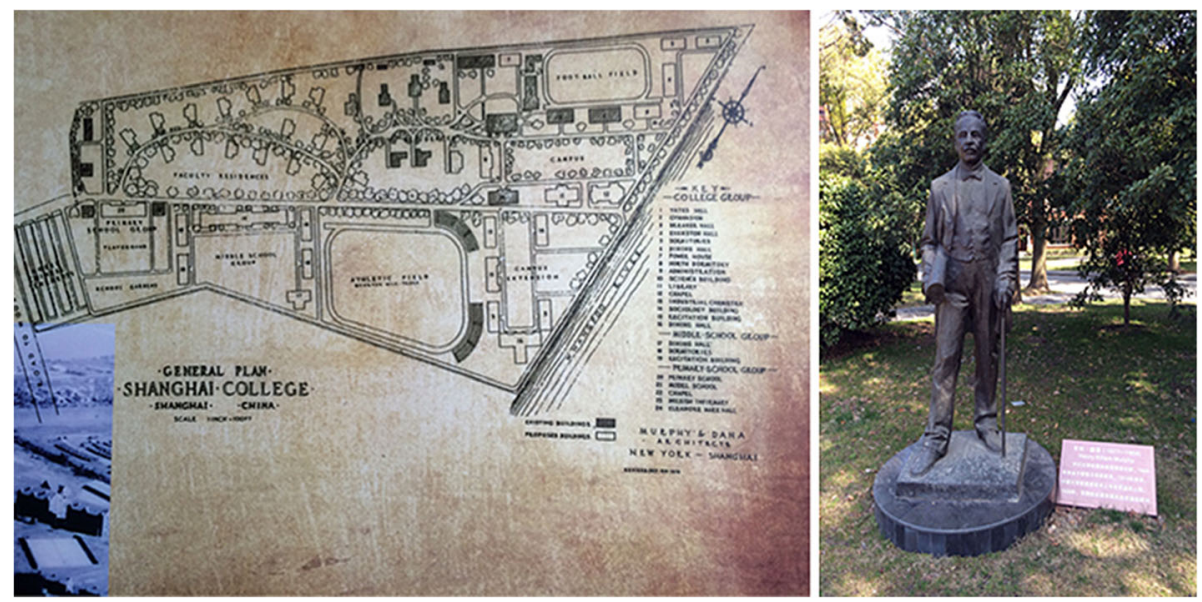

Fig. 9 Left: the general plan for Shanghai College, 1919 (Source: Archives of USST). Right: the statue of Henry Murphy (Source: the author) 
Table 7 Designated heritage architecture overview at Shanghai College

\begin{tabular}{ll}
\hline Act & Shanghai Municipal Ordinance on the Protection of Historical and Cultural Zones and Heritage Architecture \\
\hline Designated organization & Shanghai municipal government \\
Classification & Heritage Architecture (Fig. 12) \\
Designated Date & 1994,2005 \\
Manager & University of Shanghai for Science and Technology \\
\hline
\end{tabular}

categories (Lee 2019, 71-75). Shanghai College chose to sympathize with the architectural heritage. Thus, in the next section, the sympathy methods used by the campus in the process of maintaining architectural heritage are analysed.

\section{Preservation of architectural heritage and the campus identity}

Since the architectural heritage structure at Shanghai College involve a brick-and-mortar architecture, the buildings have been deteriorated by natural disasters, including fires, and ageing over the course of 100 years of history; these buildings are in the 'rehabilitation' phase defined by Robert A. Young. 'Rehabilitation' involves the act or process of preserving history, culture, and architectural values through maintenance and renovation (Young 2008).

\section{Changes in the facades of architectural heritage}

The preservation of buildings in Shanghai designated as 'heritage architecture' structures is governed by the provisions of the 'Technical Specifications for Preservation and Restoration of Historic Buildings (DG/TJ 08-1082014)'. This regulation includes the 'Inspection of Preservation and Restoration', 'Preservation and Restoration Design', 'Preservation and Restoration Construction', and 'Final Acceptance'. However, this regulation does not have coercion, but has a nature of recommendation. There was no written record of complying with this regulation in the preservation of buildings at Shanghai College. Therefore, a survey of the preservation of architectural heritage was conducted.

Since this study focuses on the effect of architectural heritage on the identity and present-day value of university campuses, the changes in the external form of architectural heritage were investigated. The exterior components of architectural heritage refer to the classification of the above regulations. The regulations are related to the preservation of the facade of architectural heritage buildings, including the cleaning, preservation and restoration of roofs, walls, columns, windows, canopies, balconies, stairs, chimneys, handrails, decorative elements, etc. (Article 5.3.1, p.19). Among them, this study focuses on roofs, facade components and colours, which correspond to the main components of the architectural heritage form at Shanghai College.

In this study, using photographic data, literature reports, and field surveys, the changes to the facade components that occurred in the preservation of architectural heritage based on the design of Henry Murphy are analysed.

\section{Roofs}

In this study, the changes to roofs during the repair of buildings following damage due to natural disasters, ageing, or other causes are examined.

In modern Chinese architecture, the roof has lost its symbolism inherent in the traditional rating system. In the repair of architectural heritage, gable roofs were converted to flat roofs. Most buildings were generally repaired in the 1960s-1980s, with an emphasis on the use value than the historical value of architectural heritage structures. The repaired buildings were used as office spaces and student dormitories. Therefore, flat roofs were far more favourable considering the repair budget (Table 8).

\section{Facade component}

As described above, the gable roofs were converted to flat roofs, but the building facades were not significantly changed when repaired. For example, for the Auditorium \& White Chapel and Richmond Hall, only the chimneys were removed in the repair process, and for Haskell Gymnasium, only white moulding was added at the ridge of the roof (Table 9).

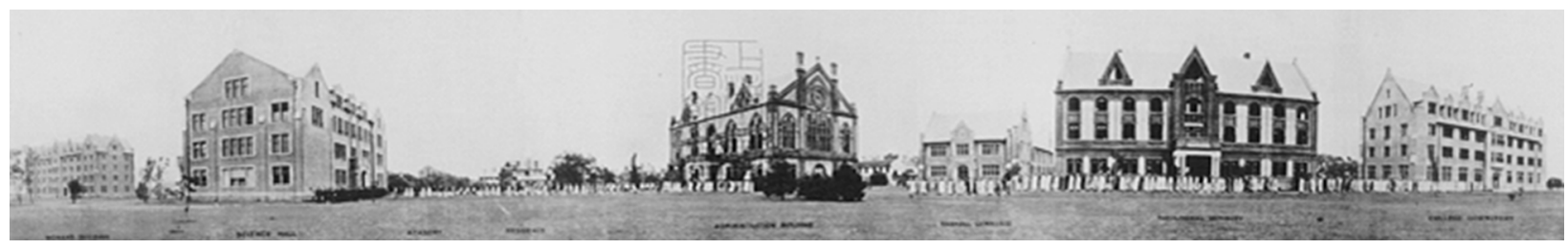

Fig. 10 Panorama of Shanghai College, unknown dates (Source: Archives of USST) 
【College Group】

1. Yates Hall* 7. Power House

2. Gymnasium* 8. North Dormitory

3. Breaker Hall* 9. Administration*

4. Evanston Hall* 10. Science Building

5. Dormitories

11. Library

6. Dining Hall*
12. Chapel

13. Industrial Chemistry

14. Sociology Building

15. Recitation Building*

16. Dining Hall
【Primary School Group】

20. Primary School

21. Model School

22. Chapel

23. Mcleish Infirmary*

24. Eleanore Mare Hall

25. Faculty Residences*

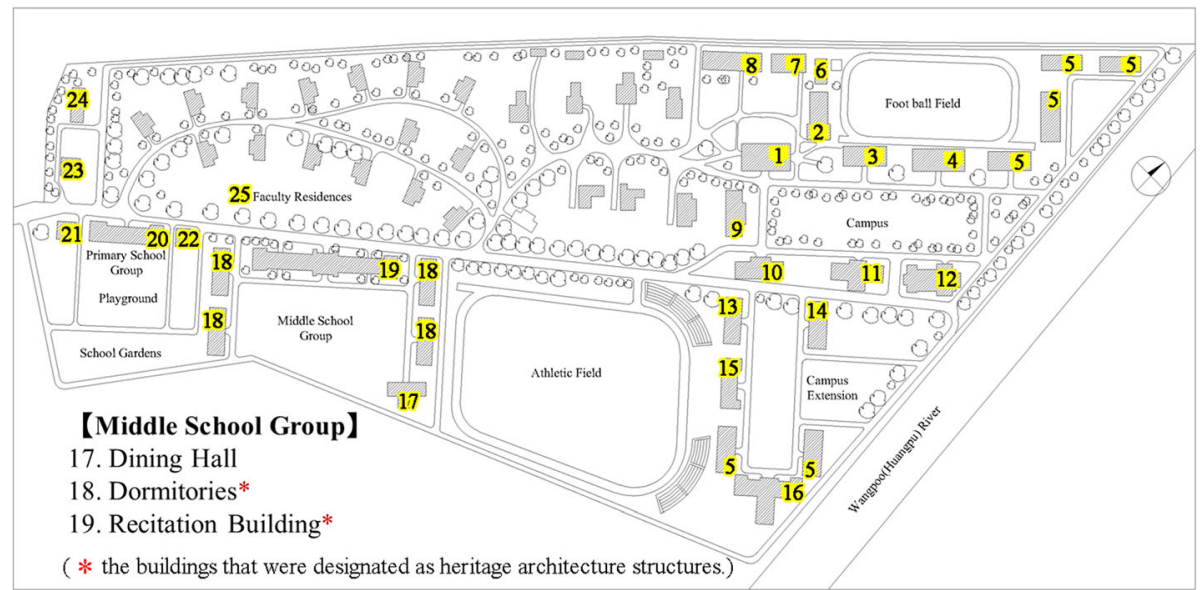

Fig. 11 The general plan for Shanghai College (Source: Hong 2016, 472)

1. Yates Hall

2. Gymnasium

3. Breaker Hall

4. Evanston Hall

5. Faculty Residences

6. Dining Hall (East Hall)

7. Mcleish Infirmary

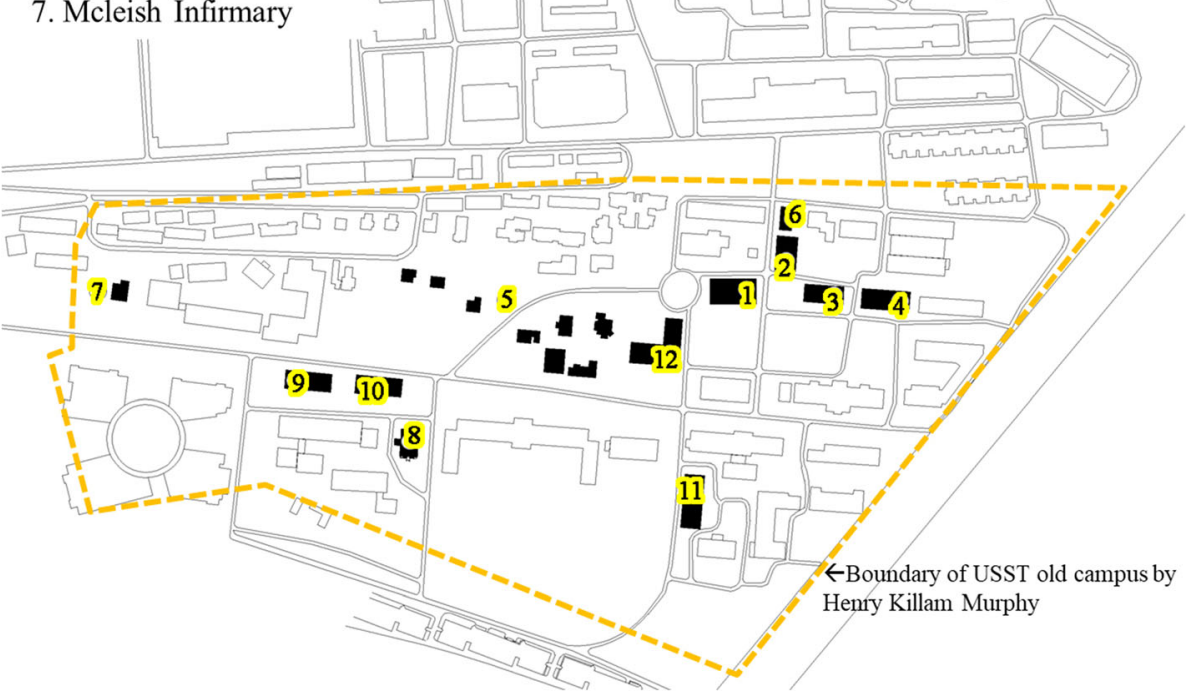

Fig. 12 List and locations of heritage architecture structures on the current campuses (Source: Hong 2016, 474) 


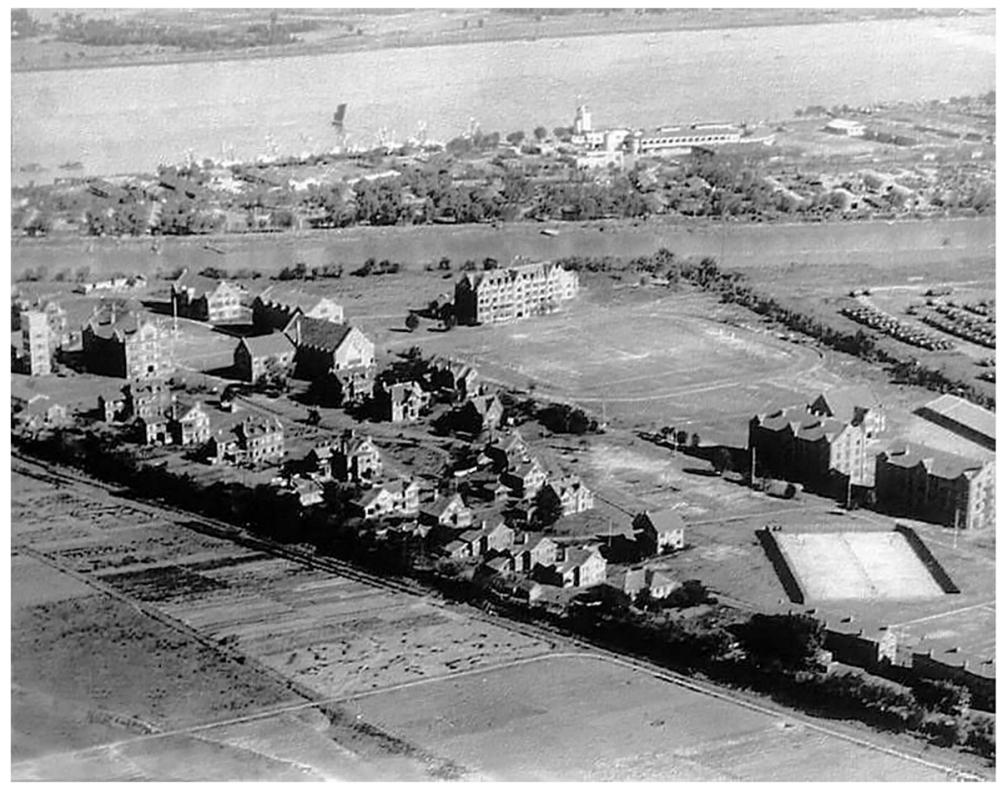

Fig. 13 Shanghai College under construction (Source: Archives of USST)

Table 8 The changes in roofs (Image source: Archives of USST)

\begin{tabular}{|l|l|l|}
\hline $\begin{array}{c}\text { Yates Hall, } \\
\text { Rebuilt in 1957 }\end{array}$ & \multicolumn{1}{c|}{$\begin{array}{c}\text { Breaker Hall, } \\
\text { Rebuilt in 1967 }\end{array}$} & $\begin{array}{c}\text { Treat Hall, } \\
\text { Rebuilt in 1984 }\end{array}$ \\
\hline Rebuilt in 1963
\end{tabular}


Table 9 Changes in the facades (Image source: Archives of USST)

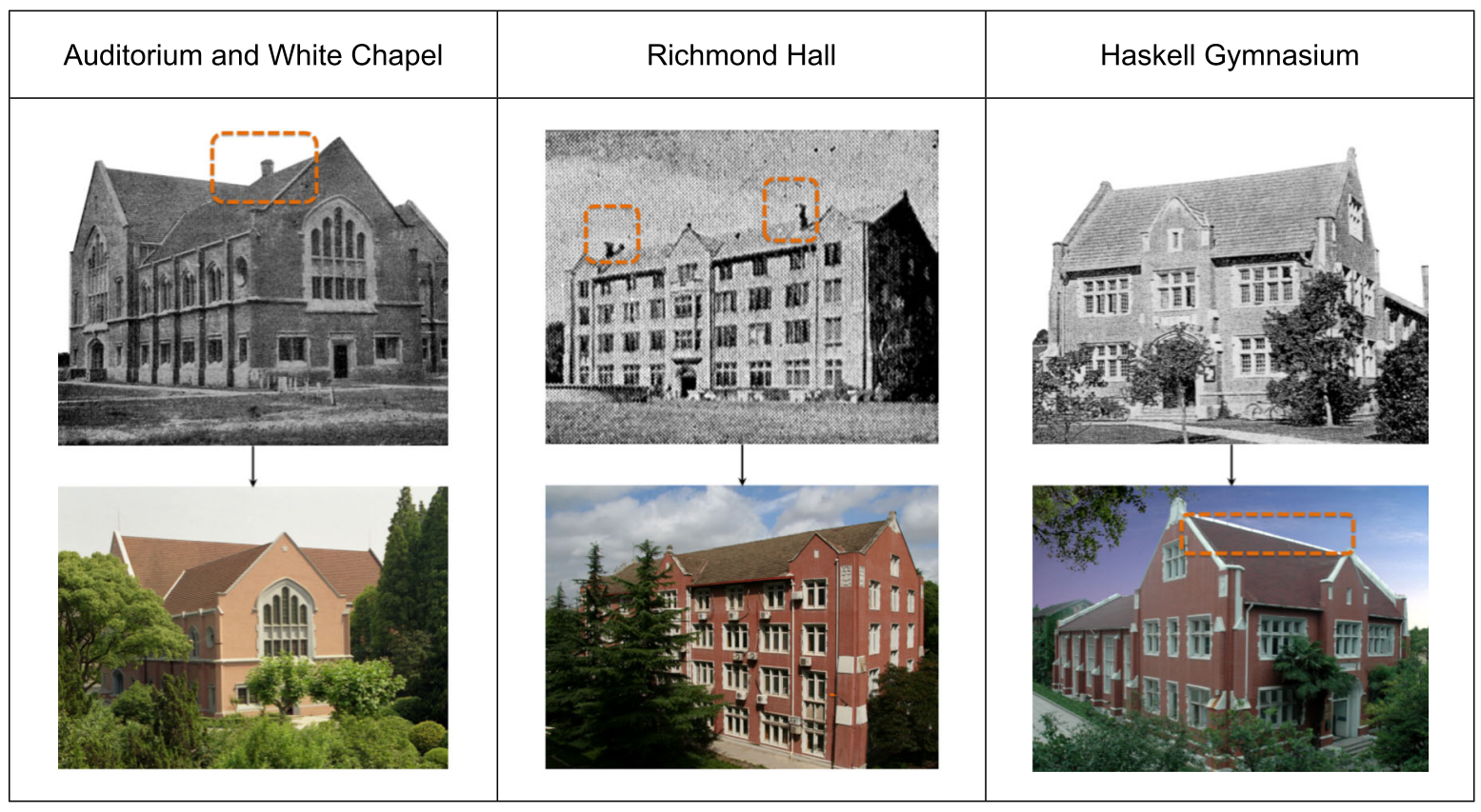

Windows in office and dormitory buildings were replaced with aluminium windows while maintaining the existing frames of the windows, which did not cause any major changes in the facades.

\section{Colours}

The campus includes a unified colour scheme for buildings that respects the architectural heritage value and establishes a university identity. The architectural heritage structures designed by Henry Murphy were mainly brick-red because bricks were used as an exterior finishing material. The contemporary architecture on the campus, regardless of the exterior finishing material, is red brick colour as much as possible (Fig. 14).

However, bricks could not be used in some cases because of restrictive conditions. These walls were therefore painted red with white lines to resemble red bricks, a style consistent with the design of the existing buildings (Hong 2016, 476). This repair method was adopted for buildings such as Edmund Hall and Richmond Hall. The newly constructed buildings were also given a brick effect on the exterior, regardless of the construction materials used or structural design, to reflect the architectural heritage (Table 10).

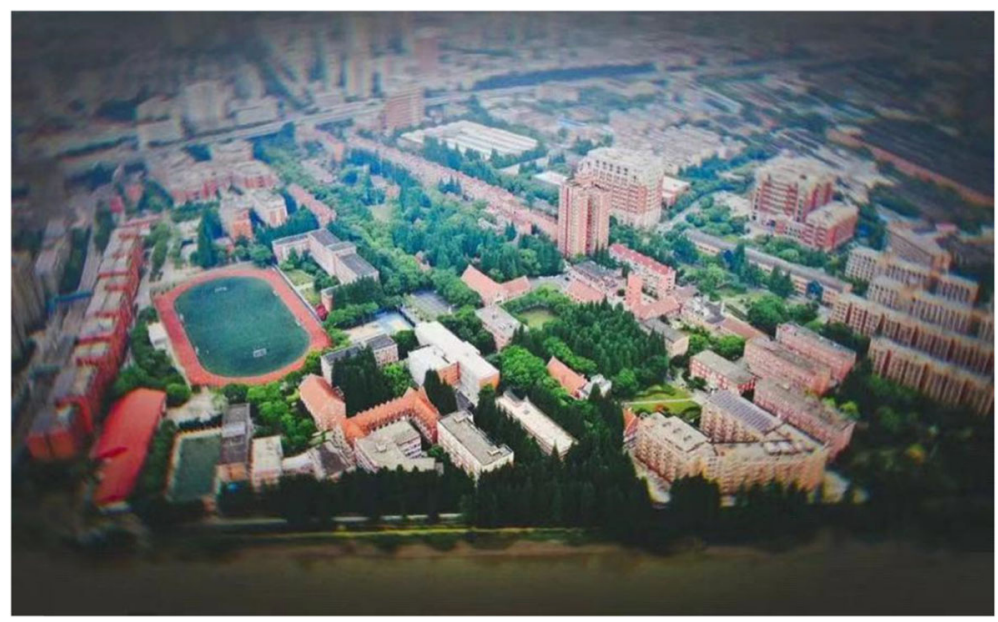

Fig. 14 Bird's-eye view of Shanghai College (Source: Archives of USST) 
Table 10 Examples of the facade colours (Image source: the author)

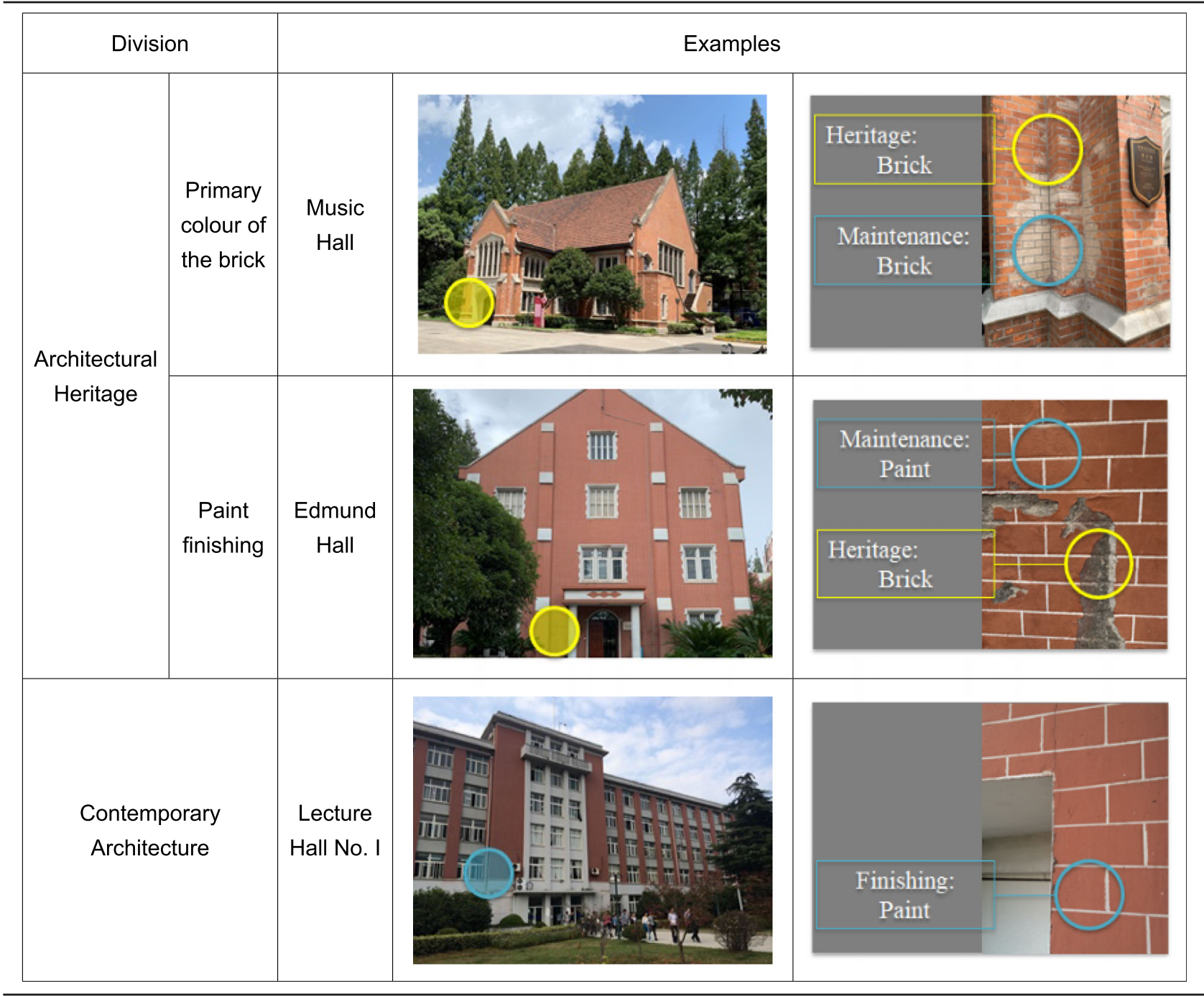

Music Hall has changed some appearance; repairs to cladding, can be clearly distinguished from the original brick finishing materials, and this difference is not consistent with the principle of colour unification.

\section{The spatial experience sequence}

In this study, the relationship between architectural heritage and campus space is analysed through changes in the spatial experience sequence and the connections among architectural heritage, the designed axis and the exterior space.

Objects in the city images can be classified based on Kevin Lynch's five types of elements: paths, edges, districts, nodes, and landmarks (Lynch 1960, 46-48). Based on these five physical elements, the composition of the nodes, landmarks, and architectural heritage structures connected through the main path planned by Henry Murphy is analysed.

On the current campus, the original gate of Shanghai College, which was erected in 1916, was rebuilt. Furthermore, the gate is connected to the main path, and on the sides of the gate are the architectural heritage buildings and the exterior space, which maintain a form similar to that in the early days of campus construction (Fig. 15). The nodes form a square with landmarks. The chairman Mao statue was used as a landmark in the square, and the statue of Henry Murphy was installed in the exterior space. This spatial experience sequence is highly similar to the campus space established in the early stages of construction.

\section{Discussion and conclusion}

In this study, the preservation of architectural heritage based on the foreign-style campus planned by Henry 


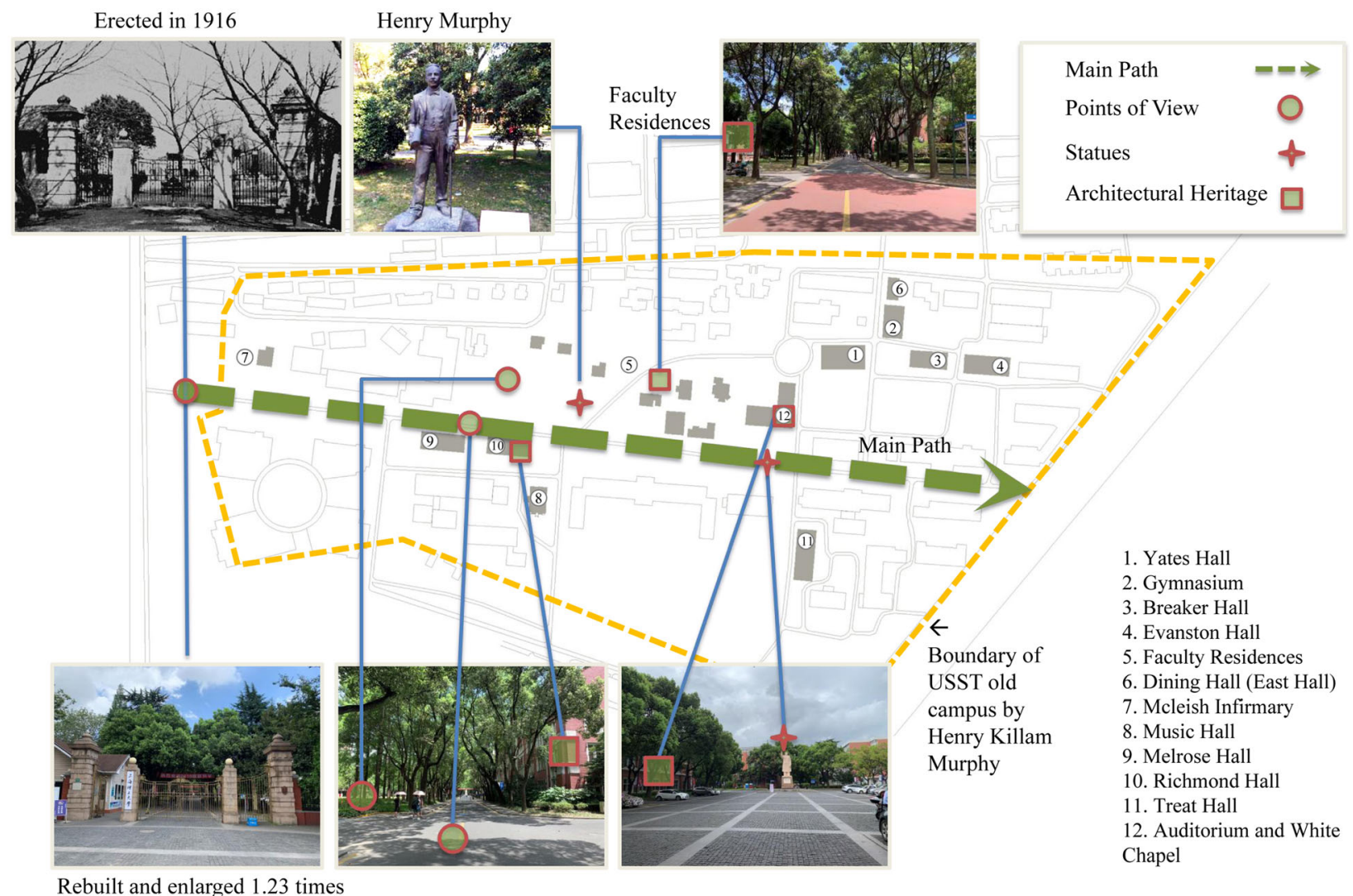

Rebuilt and enlarged 1.23 times of the original gate in 1992

Fig. 15 The spatial experience sequence effect of the main path (Source of the image on the top left: Archives of USST. Source of other images: the author)

Murphy was analysed. Chosen Christian College has focused on maintaining the authenticity of buildings, and Shanghai College has tried to consolidate the identity of the campus through the spatial experience of the architectural heritage group and the preservation of architectural heritage buildings. Thus, Shanghai College was more influenced by Henry Murphy's master plan in the development and growth of the campus and has attempted to maintain the concept of the architect and the image of the campus. Chosen Christian College was able to retain the original campus shape over nearly a century with the use of all-stone buildings, as Henry Murphy's designed, but no significant trace of the early general plan remains.

From 1914 to 1935, Henry Murphy worked on a number of campus projects as well as architectural design in Shanghai. Now that a century has past, the architecture he had designed became valuable as an architectural heritage, and the campus has also grown and evolved. Our generation is therefore obliged to reevaluate the value of these cultural assets, and to give them the value that is fitting to the present time through proper conservation methods.
The preservation of and respect for architectural heritage value are important factors in modern cities. The university campuses in East Asia that were planned and designed by Western architects through Western missionary work must be studied considering the inherent architectural heritage. Additionally, this heritage should be considered in established a campus identity and assessing value. Accurately establishing the correlation between architectural heritage and the development of a campus is important for sustainable development. In this context, an actual condition survey of campuses in two countries planned by an architect was conducted. Data on the effect of architectural heritage on the identity and present value of university campuses will be accumulated, and a more systematic system will be established.

\footnotetext{
Abbreviations

[i.e.]: id est.; [UNESCO]: United Nations Educational, Scientific and Cultural Organization; [Ref]: Reference; [DG/TJ]: Difang Gongcheng/Tui Jian, reflecting the recommended specifications for local projects
} 


\section{Author's contributions}

This article independently completed by a single author. The author read and approved the final manuscript.

\section{Authors' information}

Not applicable.

\section{Funding}

Not applicable.

\section{Availability of data and materials}

Shanghai College (University of Shanghai for Science and Technology, China): Archives of USST (offline)

Chosen Christian College (Yonsei University, Republic of Korea): Cultural Heritage Administration of the Republic of Korea (http://www.cha.go.kr). Henry Killam Murphy Papers: Yale University Library (https://archives.yale.edu/ repositories/12/resources/4816).

\section{Competing interests}

The authors declare that they have no competing interests.

Received: 15 May 2020 Accepted: 17 September 2020

Published online: 22 October 2020

\section{References}

An, Dai-Whan. 2014. Comparison with the elevation composition of underwood hall, Appenzeller hall and Stimson hall in Yonsei University (in Korean). Journal of the Architectural Institute of Korea Planning \& Design 30 (10): 123-132.

Chang, Qing. 2014. Lishi jianzhu baohu gongchengxue-tongji chengxian jianzhu yichan xueke lingyu yanjiu yu jiaoyu tansuo [envisioning historic place: Urban and rural architectural heritage conservation field at Tongji University]. Shanghai: TongJi University Press.

Cody, Jeffrey W. 2001. Building in China: Henry K. In Murphy's adaptive architecture, 1914-1935. Hong Kong: The Chinese University Press.

Cultural Heritage Administration of the Republic of Korea. 2013a. A Precise Survey of Appenzeller Hall at Yonsei University (in Korean). Seoul: Cultural Heritage Administration of the Republic of Korea.

Cultural Heritage Administration of the Republic of Korea. 2013b. A Precise Survey of Underwood Hall at Yonsei University (in Korean). Seoul: Cultural Heritage Administration of the Republic of Korea.

Cultural Heritage Administration of the Republic of Korea. 2013c. A Precise Survey of Stimson Hall at Yonsei University in Seoul (in Korean). Seoul: Cultural Heritage Administration of the Republic of Korea.

Dho, Sun-Boong. 2002. The characteristics of American Presbyterian missionary architecture in Korea from 1884 to 1945 (in Korean) PhD diss., Chungbuk National University.

Dong, Li. 2010. Zhongguo jindai jiaohui daxue jianzhushi yanjiu [a history of Christian Mission school buildings in China]. Beijing: Science Press.

Goodchild, Lester F. 2000. Oxbridge's Tudor gothic influences on American academic architecture. Paedagogica Historica 36 (1): 266-298.

Gresnigt Dom Adelbert, O.S.B. 1928. Building of Catholic University of Peking. Chinese Architecture 4: 35-36.

Hitchcock, Henry Russell. 1963. World architecture: An illustrated history. Feltham: The Hamlyn Publishing Group.

Hong, Yan. 2016. Shanghai college: An architectural history of the campus designed by Henry K. murphy. Frontiers of Architectural Research 5 (4): 466-476.

Ito, Chyuta. 1984. Zhongguo jianzhu shi [history of Chinese architecture]. Shanghai: Shanghai Bookstore Publishing House.

Jang, Sun-Young, Seongjun Kim, and Sung-Ah Kim. 2019. Designing augmented spatial experiences of architectural heritage-Information modeling for intelligent content service platform (in Korean). Journal of the Architectural Institute of Korea Planning \& Design 35 (4): 15-24.

Lamprakos, Michele. 2014. Riegl's modern cult of monuments and the problem of value. Change Over Time: An International Journal of Conservation and the Built Environment 4 (2): 418-435.

Latourette, Kenneth Scott. 1929. A history of Christian missions in China. New York: The Macmillan Company.

Lee, Kwan-Seok. 2019. The coexistence of laminated history and modern architecture in Europe: In case of modern museum architecture built near important cultural assets of UNESCO world heritage (in Korean). Journal of the Architectural Institute of Korea Planning \& Design 35 (6): 69-80.
Lee, Sang-Yun. 2012. Stimson hall, Underwood Hall \& Appenzeller Hall in Yonse University (in Korean). Educational Facility 19 (4): 26-29.

Liang, Sicheng. 1991. Tuxiang Zhongguo jianzhushi [a pictorial history of Chinese architecture]. Beijing: China Architecture \& Building Press.

Lynch, Kevin. 1960. The image of the City. Cambridge: The M.I.T Press.

Ruskin, John. 1849. The seven lamps of architecture. London: Smith, Elder \& Co..

Shin, Jee-Seop. 2006. Characteristics of the styles of school building erected by Western missionaries in Korea, 1880 1950' (in Korean) Master diss., Yonsei University.

UNESCO. 2015. Monticello and the University of Virginia in Charlottesville Accessed May 17, 2020. https://whc.unesco.org/en/list/442.

Wu, Jiang. 2001. "Jindai zhongguo siying jianzhu sheji shiwusuo lishi huigu." [review on contemporary private-owned architectural design firms in China.]. Time+Architecture 1: 12-15.

Yale University Library. 2015. Guide to the Henry Killam murphy papers https:// archives.yale.edu/repositories/12/resources/4816.

Young, Robert A. 2008. Historic preservation technology. Hoboken: Wiley.

\section{Publisher's Note}

Springer Nature remains neutral with regard to jurisdictional claims in published maps and institutional affiliations.

\section{Submit your manuscript to a SpringerOpen ${ }^{\circ}$ journal and benefit from:}

- Convenient online submission

- Rigorous peer review

- Open access: articles freely available online

- High visibility within the field

- Retaining the copyright to your article

Submit your next manuscript at $\boldsymbol{\nabla}$ springeropen.com 